JOURNAL OF SECURITY AND SUSTAINABILITY ISSUES

ISSN 2029-7017 print/ISSN 2029-7025 online

2019 December Volume 9 Number 2

http://doi.org/10.9770/jssi.2019.9.2(26)

\title{
Scopus
}

\section{DOES THE EDUCATION, HEALTH AND EMPLOYMENT DETERMINE THE ECONOMIC GROWTH: A CASE STUDY}

\author{
Somdech Rungsrisawat ${ }^{1}$, Chayongkan Pamornmast ${ }^{2}$ \\ ${ }^{1}$ Faculty of Management Science, Suan Sunandha Rajabhat University, Bangkok, Thailand \\ ${ }^{2}$ Faculty of Business Administration, Mahanakorn University of Technology, Bangkok, Thailand \\ E-mails: ${ }^{1}$ somdech.ru@ssru.ac.th; ${ }^{2}$ chayongkanp@hotmail.com (corresponding author)
}

Received 23 February 2019; 27 October 2019; 30 December 2019

\begin{abstract}
Economic growths are often used to measure the development of a country. Thus, the economic growth is what every economy tries to achieve for good of everyone as a whole. In the other hand education, health and employment are one the most important tool for the economy growth. Thailand as developing countries concern about the economy growth and done an investment in through it. The general objective of this paper is to examine the relationship between education, health, employment and economic growth in Thailand from 1988 to 2017. The econometric method is used to examine the relationship between education, health, employment and economic growth. Unit root test indicate that all of the above variables are I (1). Johensen's test was conducted to see the long run relationship between these variables. Meanwhile the relationship is test by using Ordinary Least Square and the Granger Causality test. The relationship between education with the economic growth are examine by using the literacy rate as education proxy variable. The health variable is examining by using the infant mortality rate, life expectancy and crude death rate with the GDP and the employment are examine by using the total employment rate with the GDP. As conclusion the results shows the positive relationship between the three variables with the economic growth and suggestion to the Thailand economic to do more investments in this variable. The findings of this study can be used to generate concrete policy reform suggestion and also used as guideline or example for other developing countries.
\end{abstract}

Keywords: Health; Employment; Education; Economic growth

Reference to this paper should be made as follows: Rungsrisawat, S., Pamornmast, Ch. 2019. Does the education, health and employment determine the economic growth: a case study, Journal of Security and Sustainability Issues 9(2): 701-714.

http://doi.org/10.9770/jssi.2019.9.2(26)

JEL Classifications: 01, 016

\section{Background}

The main aim of the study is to examine the relationship between education, health, employment and economic growth in Thai. The main purpose of this paper is to show that this three-variable playing a role as economic tool in the Thai growth and suggestion will be provided so that the government can give concern on this variable in developing the nations. The statement above clearly state that the education and health are important in developing a nation and it's also showing that the health and economic have two-way relationship which means both of this variable have correlated each other in helping the nations development. Idris and Rahmah Ismail as note that the Thai economy growth is now in the era of knowledge - based economy and the role of human capital has a direct relationship with worker productivity, hence contributing positively to economy (Fleming, 2017). As per stated in the purpose of this study to examining the relationship between education, health, employment and economic growth. Thai at the moment in the new economy model which means the concerns is given more to the human capital (Fleming, 2017). Human capital development includes education, health and 
productivity. Productivity depends on the employment rate. Other than that, there is existing studies to examining the relationship between the health, education and economic growth (Panfiluk, Szymańska, 2017; Reinhold et al., 2019; Chistobaev et al., 2018; Gomes et al., 2018; Bernardi, 2019). Besides, there is study have been done thorough out the health, employment and economic growth. The Thai government spends a lot to improve the education, health and employment for the positive growth rate. the issue here to examining the relationship between this three variable towards the economy growth and does this three variables important to the economy growth until the government spending increase from the year to the year (Haile \& Niño-Zarazúa, 2018). In other hand, there is none of the studies have been done to examining relationship between education, health, employment and economy growth. Thus, this study has been done to examining the relationship between this variable answer those question. Does education have relationship with the Thai economy growth? Does health have relationship with Thai economy growth? And the last question is does employment has relationship with Thai economy growth? The findings of this study can be used to generate concrete policy reform suggestion and also used as guideline or example for other developing countries.

\section{Literature review}

The Effective Wage Theory advocates that a worker has receive sufficient remuneration in order for him/her to be motivated to work diligently (Jermsittiparsert, Sriyakul, \& Pamornmast, 2014). This is made possible only after one has fulfilled the basic needs. Nutritious food will not only contribute to the wellbeing of the person but also enhance the productivity of the firm (Felipe \& McCombie, 2019). In the long run even, the country will benefit from the increased productivity of the firm. A functional Approach to health brings to attention the fact that an increased number of sick individuals in particular time frame can significantly reduce the contribution to national output (Jermsittiparsert \& Sriyakul, 2014). On the other hand, societies are heavily industrialized can afford to have more sick members in society at one go compared to developing nations that depend on the availability of the human force in the agricultural and horticultural sectors (Harper, Harper, \& Snowden, 2017). Wei, Ren, and Zhou (2013) concluded in his study that there were “.... some strong patterns of interaction between growth and basic welfare." He added that expenditure on basic needs can be seen as an investment in human capital and that rapid output growth is essential for equity of life, The World Development Report (1993) argued that besides encouraging rapid income growth, it is essential to have investment in education, especially in the poor countries to strengthen the people's capacity to achieve better health (Organization, 2015).

Werfalli (2019) noted that the world's poor were mainly found in Sub-Saharan Africa and South Asia with a population of 3.2 billion and per capita income of $\$ 390$ per year. The increase in access to education and practice of preventive health care proved successful in reducing the fertility rate, from 5.6 births per woman in the 1970s to 3.3 in 1994. Bongaarts, Mensch, and Blanc (2017) concurred that education is important in alleviating the problem of poverty. When female education increases the value of women's time in economic activities, this creates a rise in household income and reduction in poverty. Smaller sized families will have a better nutritional supply, greater access to education and also benefit from the available health care system. This creates a healthy work force that will be able to contribute to the economic growth of the country. Foster (1995) noted in his study “... caloric allocations efficiently capture potential return to productivity" (Felipe \& McCombie, 2019). in a study scholar noted that an improvement in nutrition intake had accounted for about 30 percent of income per capita groeth in Britain between 1970 and 1980. Delgado and Stefancic (2017), in his study, asserted that the establishment of a comprehensive system of health care and education will be essential to counteract the social ills that a society faces. Haile and Niño-Zarazúa (2018) concluded, among others, that government spending has been important in improving the health status and education level of the poor, but still has a long way to go in many developing countries before trade-off with economic growth is generated. Khusaini (2016) noted that economic growth and productivity improvement depend on research and development, investment in plant equipment, investment in infrastructure; and investment in human resource development. Human resource development and the creation of a skilled, productive and adaptable workforce depend on the education system, healthcare, training and retraining, family policy, labor- management, policies at the workplace and the general health of public service. 
A study was conducted by Kvangraven (2016) on the countries of Sub-Saharan African. The researchers found that the performance of the countries was improved as compare with 1980s and 1990s. However, the economic performance of these countries is still behind Latin America and Asia. The economies wit high growth rate did not show low rate of poverty better opportunities of employment, decrease in gender inequalities and high attainment of education. The issues of employment exist in the countries sub-Saharan Africa. This is a quality matter rather than quantity. The reason for this is weak performance in terms of employment do not exist in the rigidities of labor market. The weak economic performance and decrease in demand of labor can explain the increase in observed working poor. The relation between labor market and economic growth was analyzed by Olusoji (2016). The researcher found that the relation between unemployment change and GDP growth is classified in two main factors. These factors include the employment changes and rate of unemployment governed by demographic influences, economic factors, and policies of labor market (Ehrenberg \& Smith, 2017). Using time series data for every country of EU and panel data for cross country analysis. A strong and positive correlation was found between employment change and growth of GDP.

Using the ratio of employment to population, employment was measured by Kareem (2015) that determines the extent with which population is involved in the productive activities in the labor market. Moreover, it is referred as the percentage of working age population in the country, which is employed. It was found that there is a positive and significant relation between employment and GDP. The findings are consistent with theoretical perspective that it is normal to have positive relation between employment and GDP (Greiner, Semmler, \& Gong, 2016). However, the development of jobless growth is not a permanent deviation, as employment can occur soon.

A paper was published by Verdoorn in late forties in which a linear and close relation between productivity of labor and growth of industrial output was stated in long run. It was found by Verdoorn that the productivity elasticity with regard to industrial production was .45 . This was used for prediction of productivity (Felipe \& McCombie, 2019). The productivity elasticity was defined by Verdoorn and Kaldor as the reflector of increasing returns to scale because of higher labor division. The findings of cross-country analysis of Kaldor showed that these were similar to the results of Verdoorn. According to findings, when there is 1 percent increase in output growth, this results in increase of 0.5 percent in employment growth. It is important to note unemployment cannot be controlled easily, when there is greater effect of productivity on growth (Piore, 2017).

\section{Model}

In this section, the discussion is focused on the specification of the model and divided the data for Gross Domestic Product and variables. This paper employed the ordinary least square test methodology to examining the direction of the relationship between GDP with education, health and employment in Thai. To verify the variables, Augemented Dickey Fuller (ADF) Unit Root Test based on well-known Dicker- Fuller producer is used. The Granger Causality tests are employed to test the correlation and possible relationship among the variables and the economic growth. This econometric test is forgoing with correlation test on the variable employed in the study (Rafindadi, 2016).

The idea of economies to growth or generate higher economic surplus was developed by the Western countries in the initial modern period. The developed surplus could be used on other things rather than subsistence. For instance, it can be incurred on warfare, religious projects, consumption, etc. as per the traditional view, surplus can be generated by increase in tax rates or population in the country. The growth of economy is referred as the reorganization and replacement of human activities supported by investment for maximization of returns (Farley \& Voinov, 2016).

The development of cultural systems and life support, which is self-organized, is highly flexible and creative but unpredictable as well. The self-organizing systems are difficult to form, and mixed results have been produced by developing evolution of economies in long term. Increase in the total amount of specie, which is the medium of circulation (gold or silver), was referred as growth in the period of Mercantilist (Pred, 2017). Because of this theory, policies were developed to impose trade through a specific state. The cheaper supply of 
raw materials was acquired by colonies that can be sold after manufacturing.

Afterwards these policies were regarded as to promote domestic industry and trade. The $18^{\text {th }}$ century policies were because of the improved manufacturing capability because of which raw materials were imported and finished goods were exported referred to the post-Bullionist insight. The manufacturers were allowed to develop factories under the high tariffs system. Fixed costs of capital growth were paid by local markets and these were allowed for export internationally by undercutting the manufactured goods prices (Schwartz, 2019).

As per the growth theory, monopolies were granted to improve growth, which offer incentive to use a resource or market. The individual has the confidence to generate profits by eliminating the competitors from business. Such examples include British East India Company and Dutch East India Company, which were given monopolies by the state. It was considered in this period that advantageous trade could result in growth (flow of specie within the country). However, it was disadvantageous to trade with other countries on equal terms. In Mercantilism, it was not just the restriction of trade. It was regarded as the elimination of trade barriers within a country and development of new roads by destructing the local booths. The aim was to expand the markets. This referred to the power centralization in the Crown's hands the modern nation state was produced by this process in Western Europe. Contradiction was resulted from Mercantilism at international level. Trade lead to growth. However, it was disadvantageous to trade on equal terms with other countries (Munim \& Schramm, 2018). The criticism of Mercantilism leads to the modern concept of economic growth. This modern political economy was founded by the physiocrats and scholars of Scottish Enlightenment i.e. Adam Smith and David Hume. These scholars suggested that growth is allowed by the productivity capacity and increase of capital result in generation of "the wealth of nations" (Salter \& Young, 2019). However, the significance of agriculture was emphasized by these scholars and urban industry was considered as sterile. It was argued by David Ricardo that a country could be benefited by trade. When cheap things can be sourced from abroad, it is profitable to buy from there. This is referred as comparative advantage theory, which is the base for trade across countries. Therefore, free trade is crucial for growth of economy.

The Growth Model of Solow-Swan is referred as growth because of increased level of capital goods. A series of equations are involved in the model that represents the relation between capital goods, investment, labor time, and investment. Technological change has a crucial role as compared with capital accumulation. In 1950s, the long growth was analyzed by Robert Solow and Trevor Swan by the development of this model. It is assumed in this model that resources are efficiently utilized by countries and labor increases and capital has diminishing returns.

Three key predictions are made by the neoclassical model from these two aspects. Economic growth is created by increasing capital relative to labor. With more capital, people become more productive. Moreover, there will be faster growth in the countries with less capital per person as every capital investment will result in greater returns as compared with the rich economies with sufficient capital (Aghion, Comin, \& Tecu, 2016). Further, a point will be reached by countries due to diminishing capital returns. At this point, economic growth will not be influenced by increase in capital. This state is referred as steady state. This steady state can be overcome by the countries by technological developments. The rate of savings determines the per capital output in long run.

However, the rate of growth in output must equate with rate of any saving. The process of continued growth of countries irrespective of the diminishing returns is explanatory in this model. It shows the development of innovative technology, which allows the production using limited resources. The capital level increases with improvement in technology at the steady state. The economy grows with investments in the country. The predictions of this model for similar growth rate for all countries in long run have not been supported by the data. Moreover, the faster growth of poor countries until the steady state is reached is not fulfilled by data (Samargandi, Fidrmuc, \& Ghosh, 2015). It is suggested by the data that growth rate of world has increased at a low rate. It has been shown by the modern economic research that there is no evidence for the support of neoclassical economic growth model. It was claimed by the calculations of Solow that most of the economic growth is because of development of technology as compared with the labor and capital inputs. 
However, it has been found by the recent economic research that the labor input and investment changes have not been taken into account by the calculations. In 2000, the president of American Economic Association Dale Jorgenson, of Harvard University, found that most of the residual of Solow is explained by the changes in capital quality, investment goods, and labor inputs. It has been estimated that more than $85 \%$ growth is accounted by the labor and capital inputs for years $1945-1965$. However, $15 \%$ is because of growth in productivity (Rabushka \& Kress, 2019). This shows the rapid obsolescence of earlier research on productivity using Kuznets and Solow convention. The theories developed by Paul Romer in 1980s and 1990s made advancements in the theory of growth.

Some new theories of growth include Robert J. Barro and Robert E. Lucas. Economists were not satisfied with the explanation of Solow and tried to endogenize technology during 1980s. The theory of endogenous growth was developed, which included explanation for advancements of technology in mathematical terms. A new concept of human capital is involved in this model along with knowledge, skills, which lead to productivity of workers (Fleming, 2017). There are increase rates of return for human capital unlike physical capital. The capital has constant returns and steady state is never reached by the economies. With the accumulation of capital, growth is not slowed. However, it is based on different types of capital investments made by a country. The focus of research in this domain is based on the factors increasing human capital such as technological change or education.

It has been suggested by the recent empirical analyses that cognitive abilities differences linked with schooling and some other factors lead to changes in rate of growth across the countries. Knowledge and intelligence are involved in cognitive abilities and these are crucial than education. These abilities are relevant as compared with the factor of economic freedom in classical growth theory (Rindermann, Kodila-Tedika, \& Christainsen, 2015). Comparatively, the level of competence of high ability group is crucial than low and mean ability groups in the societies. This is improved through innovation, growth, research and other elements such as democracy.

\section{$Y=f($ education, health, employmnet $)$}

$\mathrm{Y}$ in the equation above represents Thai Gross Domestic Product (GDP). Meanwhile the variable Edu represent education and the proxy variable for education is literacy rate. In other hand, health representing infant mortality rate, life expectancy rate and crude death rate proxy variables (Bader \& Ganguli, 2019). Employment variables represent the total employment rate. $\mathrm{Y}$ in the equation is states as dependent variable and other three variables in the equation are known as independent variable. This equation states merely that at any moment, the economy growth has relationship between education (literacy rate), health (infant mortality rate, life expectancy rate and crude death rate) and employment (total employment rate). The finding of this study is expected to show that economy growth has the positive relationship if the education variable increase, health variable increase (expectancy rate) and decrease in the (infant mortality and crude death rate) and increase in the employment (total employment rate).

Gross Domestic Product (GDP) GDP may therefore be viewed as rough indicator of a nation's property. Nevertheless, GDP are commonly used to examining the economic performance and the relationship between other variables (Ozturk, 2016). In other hand, GDP are used to measure the nation's economy growth which means the positive impact are seen if the GDP have positive correlation with the variable tested.

Literacy rate: It is referred as the ability to write and read. Different theoretical aspects have defined this concept differently. According to the UNESCO, it is the ability to identify, communicate, interpret, and use different written and printed contexts. Literacy rate is one of the health variables which gives the impact to the economy growth. In human capital theory by Gary Becker showing that education has positive impact towards the nations growth (Shuaibu, 2016).

Infant mortality: It is referred as the total number of deaths of infants aged between 0-1 per live births of 1000 . 
The diarrhea has been the main reason, which causes dehydration. The rate of children dying from dehydration has decreased with the increase in awareness regarding Oral Re-hydration Solution, which is a combination of sugar, water, and salts). Ijaz (2018) shows that the growth of the nation's economy depends on the infant mortality too. Whereby decrease in this variable will show the positive impact towards the economy growth.

Life expectancy: it is the number of expected life years left at a specific age. This is represented by ex that shows the average number of previous years of someone aged $\mathrm{x}$ at present, as per the specific experience of mortality. It used as one of the health variables to examining the relationship with the GDP. Ijaz (2018) has been said that the life expectancy is one of the important indicators in the economy growth and has positive relationship with the economy growth. Increase in life expectancy will contribute to the economy growth.

Crude death rate: It is regarded as the total deaths (in numbers) in a specific geographical region such as state, country, etc, divided by the total number of populations in the same region, and multiplied with 10000 . It is determined for specific time, most commonly a calendar year. Beville (2018) in their arguments said that the fall in death rates gives the positive impact to the nation's economic growth.

Employment: Total employment rate are used to examine the relationship between the employment rates with GDP. Kareem (2015) found a significant and positive relationship between GDP and employment. Increase in the total employment show as positive relationship with GDP.

$\operatorname{lnREGDP}_{i t}=\gamma_{0}-\gamma_{1} \operatorname{LnEdu}_{i t}+\gamma_{2} \operatorname{Lninf}_{i t}+\gamma_{3} \operatorname{LnExptR}_{i t}+\gamma_{5} \operatorname{LnCr}_{i t}+\gamma_{6} \operatorname{LnEmploye}_{i t}+\varepsilon_{i t} \ldots \ldots \ldots$

Longarathima terms will be impose in the equation above as the variable data collected in the percentage while the GDP in term of million. Thus Jeffery M Wooldridge (2009) in this book of introductory econometric modern approach finds that a multiple regression model suffers from functional from misspecification when it does not properly account for the relationship between the dependent and the observed explanatory variable. Equation (1) $R E G D P_{i t}$ shows the economy growth thru the GDP where is a GDP, $E d u_{i t}$ representing the literacy rate, ExptR represent the infant mortality rateand representing the life expectancy rate, $\operatorname{Cr} D$ represent the crude death rate, represent the total employment rate and the is the error term. The constant is denoting $\gamma_{0}$ for while $\gamma_{1} \ldots \gamma_{6}$ are the coefficient show how much a unit of increase in each variable will affect the economy growth.

\section{Data and Estimation}

This test is used to analyze about the stationary or non-stationary data involved in research analysis. When the trend of time series variables does not have movement (upward and downward) with time, it is called stationary. The values of autcorrelation, variance, and mean of the data are constant with time in case of stationary data (Gujarati, 2006). When these requirements are not met by the variables involved in time series, the data is non-stationary. To obtain valid statistics of $\mathrm{F}$ and $\mathrm{t}$ values, the time series data must fulfill the stationary conditions (Hossain, 2008). Mostly, the test of Dickey-Fuller is used as unit root. The stationarity of the variables is tested by unit root test. For this, ADF/DF is applied (Enders, 1995; Jeffrey M Wooldridge, 2016). In this process, the OLS method is used to obtain the t-statistics by regressing equation. There is white noise error term involved that has unit variance and zero mean. The Tau statistics are used in the calculations that are tested for null hypothesis against the alternative hypothesis (MacKinnon, 1991). When the variables stationary at level, this means unit root exists. When the variables are stationary at first different, they are regarded as integration of $1^{\text {st }}$ order. If it requires second difference to make the variables stationary, these are referred as stationary at $2^{\text {nd }}$ difference and so on. In case, the above assumption is violated, the equation is modified into 3.3 using lagged changes of $\mathrm{p}$ in the endogenous variable using additional regression. This has been shown as below:

In Dickey-Fuller test, the null hypothesis and alternative hypothesis are as below:

H0: $\mathrm{B} 1>0$

$\mathrm{H} 1: \mathrm{B} 1<0$ 
The model specification is the central concept in the cointegration. This involves the long run movements of a variable in relation to the other variables. In explanation, the existence of long run equilibrium association between the variables is clarified. When the variables in time series show stationarity at level, they can be integrated with first order. The cointegration of these variables can be done when there exist one or more linear relations between the stationary variables. A constant long run linear association exists between the variables when they are co integrated. Engel and Granger (1987) firstly introduced the test of co-integration and it was modified by several researchers i.e. Stock and Watson (1988) and Johansen and Juselius (1990). The suggestion of Padhan (2008) has been followed for using AIC to determine the equation 3.4's optimal specification. The suitable order of the model is evaluation through calculating the above-specified equation over selected values and $\mathrm{k}$ lag. The $\mathrm{p}$-value is found at which the minimum AIC is attained. The study used the critical values of MacKinnon (1991) and ADF has non-standard distribution. It is useful in determine the relation of long run equilibrium between variables. The approach of Johansen maximum likelihood (ML) has been used to check co-integration. It is the most appropriate and reliable technique for small size and properties of sample. This method has another key benefit, which is the estimation of several co-integration relations in a simultaneous way. Two statistics have been used for checking co-integration, which are maximum eigenvalue and trace test. Following is the process of estimating these statistics.

$$
\Delta X_{t}=A_{0}+\varphi X_{t-p}+\sum_{t=1}^{p-1} A_{i} \Delta X_{t-1}+\varepsilon_{t} \ldots \ldots
$$

$\varphi$ is the vector and $\mathrm{X}$ being the variables in the equation (3.5). Therefore, the rank of $\pi$ has been used to test the relation of long run equilibrium between the variables. Considering $r$ zero, the equation (3.5) can be transformed to pth order VAR model. There is no co-integration relation between the variables at level. Rather, there are $\mathrm{n} X \mathrm{r}$ matrices of $\alpha$ and $\beta$.

$$
\varphi=\alpha \beta^{\prime}
$$

A determines the strength of cointegration relation and $\beta$ is cointegrating vector. $\beta$ ' is integrated of order 0 .

$$
\begin{aligned}
& \sum_{v v}^{-}=\left(\frac{1}{T}\right) \sum_{T=1}^{T} \overline{v_{t} v_{t}} \ldots \\
& \sum_{p p}^{-}=\left(\frac{1}{T}\right) \sum_{T=1}^{T} \overline{p_{t} p_{t}} \ldots \\
& \sum_{v p}^{-}=\left(\frac{1}{T}\right) \sum_{T=1}^{T} \overline{v_{t} p_{t}} \ldots
\end{aligned}
$$

The maximum likelihood estimator of ' $\beta$ ' can be obtained by solving:

$$
\left[\eta \sum_{p p}^{-}-\sum_{\theta u}^{-} I N V\left(\sum_{v p}^{-} \sum_{v v}^{-}\right]=0 \ldots(7)\right.
$$

Here the $\eta\left(\eta_{1}, \eta_{2}, \ldots . \eta_{n}\right)$ reprinting eigenvalue and the normalize co-integration vector is as follow

$$
\beta^{\prime} \sum_{p p}^{-} \ddot{\beta}=I \ldots \ldots(8)
$$

In this test, the null hypothesis of $r$ co-integrating vectors is tested against the alternative hypothesis of $r=1$ co-integrating vector. Hence the null hypothesis $r=0$ is tested against the alternative $r=1, r=1$ against the alternative $\mathrm{r}=2$ and so forth. It is well known that the co-integration test very to the choice of lag length. The Akaike Information Criterion (AIC) and Scfwarz Bayesian Criterion (SBC) are used to select the number of lags required in the co-integration test. If there exist a co-integration vector between that variable, there is possibility of causality between the two at least in one direction (see Granger, 1988). Thus, Granger causality test 
can be used to examine the nature of the relationship (Engle \& Granger, 1987). If

$$
\begin{gathered}
\eta=L_{A}-L_{0}=\left(\frac{T}{2}\right) \sum_{i=h+1}^{n} \log (1-\breve{\eta}) \ldots . \\
2\left(L_{A}-L_{0)}=2\left(\left(\frac{T}{2}\right) \sum_{i=h+1}^{n} \log (1-\breve{\eta})\right) \ldots \ldots\right. \\
\eta_{\max }=-T \log \left(1-\breve{\eta}_{r+1}\right) \ldots \ldots \ldots \ldots \ldots \ldots
\end{gathered}
$$

In this test, the null hypothesis of $r$ co-integrating vectors is tested against the alternative hypothesis of $r=1$ co-integrating vector. Hence the null hypothesis $r=0$ is tested against the alternative $r=1, r=1$ against the alternative $\mathrm{r}=2$ and so forth. It is well known that the co-integration test very to the choice of lag length. The Akaike Information Criterion (AIC) and Scfwarz Bayesian Criterion (SBC) are used to select the number of lags required in the co-integration test. If there exist a co-integration vector between that variable, there is possibility of causality between the two at least in one direction (Engle \& Granger, 1987). Thus, Granger causality test can be used to examine the nature of the relationship (Engle \& Granger, 1987).

$$
\begin{aligned}
& \boldsymbol{R G D P _ { i t }}=\sum_{t=1}^{n} \beta_{i} E d u_{i t-1}+\sum_{t=1}^{n} \beta_{j} R G D P_{i t-1}+\varepsilon_{1 i t} \\
& \boldsymbol{E} \boldsymbol{d} \boldsymbol{u}_{i t}=\sum_{t=1}^{n} \beta_{i} R G D P_{i t-1}+\sum_{t=1}^{n} \beta_{j} E d u_{i t-1}+\varepsilon_{2 i t} \\
& \boldsymbol{R G D P}_{i t}=\sum_{t=1}^{n} \beta_{i} i n f_{i t-1}+\sum_{t=1}^{n} \beta_{j} R G D P_{i t-1}+\varepsilon_{1 i t} \\
& \boldsymbol{i n f}_{i t}=\sum_{t=1}^{n} \beta_{i} R G D P_{i t-1}+\sum_{t=1}^{n} \beta_{j} i n f_{i t-1}+\varepsilon_{2 i t} \\
& \boldsymbol{R G D P _ { i t }}=\sum_{t=1}^{n} \beta_{i} \operatorname{ExptR}_{i t-1}+\sum_{t=1}^{n} \beta_{j} R G D P_{i t-1}+\varepsilon_{1 i t} \\
& \boldsymbol{E x p t R}_{i t}=\sum_{t=1}^{n} \beta_{i} R G D P_{i t-1}+\sum_{t=1}^{n} \beta_{j} \operatorname{ExptR}_{i t-1}+\varepsilon_{2 i t} \\
& \boldsymbol{R G D P}_{i t}=\sum_{t=1}^{n} \beta_{i} \operatorname{Cr}_{i t-1}+\sum_{t=1}^{n} \beta_{j} R G D P_{i t-1}+\varepsilon_{1 i t} \\
& \boldsymbol{C r} \boldsymbol{D}_{i t}=\sum_{t=1}^{n} \beta_{i} R G D P_{i t-1}+\sum_{t=1}^{n} \beta_{j} C_{i r D t-1}+\varepsilon_{2 i t} \\
& \boldsymbol{R G D P}_{i t}=\sum_{t=1}^{n} \beta_{i} \text { Employe }_{i t-1}+\sum_{t=1}^{n} \beta_{j} R G D P_{i t-1}+\varepsilon_{1 i t} \\
& \text { Emplyee }_{i t}=\sum_{t=1}^{n} \beta_{i} R G D P_{i t-1}+\sum_{t=1}^{n} \beta_{j} \text { Employee }_{i t-1}+\varepsilon_{2 i t} \cdots
\end{aligned}
$$

\section{Data}

The data for this study have been drawn from four main sources: The Ministry of Finance (Economic Report), World Bank Data, Department of Statistics and also from Ministry of Information, Communication and Culture. The study covers 30 years from 1988 to 2017. There was no problem with the data collection process as regards the GDP time series where different sources are available to provide the required data for the whole study. Regarding the education, it was not possible to find annual time series for literacy rates. Three health variables and total employment data was collected from different sources. 


\section{Results}

Stationarity of variables has been checked before VAR and cointegration. When the data has constant value for mean and variance with time, it is regarded as stationary (Enders, 2004). The initial step is to check the integration at level. The past shocks create a undiluted influence and there is infinite variance and mean based on time, this is referred as integration. The test recommended by Dickey and Fuller has been used in this study to check the unit root properties for variables (ADF, 1979, 1981). When the variables are not stationary at level, these can be made stationary at first difference using similar lags level (Table 1).

Table 1. Unit Root test

\begin{tabular}{|c|c|c|}
\hline Variable & \multicolumn{2}{|c|}{ First Difference } \\
\hline & Constant & Constant and Trend \\
\hline \multirow{2}{*}{ RGDP } & $\begin{array}{c}-1.923419191[0] \\
(0.2364)\end{array}$ & $\begin{array}{c}-0.631812131[0] \\
(0.6211)\end{array}$ \\
\hline \multirow{2}{*}{ Edu } & $\begin{array}{c}-1.531812131[0] \\
(0.3451)\end{array}$ & $\begin{array}{c}-0.723234112[0] \\
(0.2271)\end{array}$ \\
\hline \multirow{2}{*}{ Inf } & $-1.739281211[0]$ & $-0.8237162111[0]$ \\
& $(0.4721)$ & $(0.7212)$ \\
\hline \multirow{2}{*}{ ExptR } & $\begin{array}{c}-1.723818011[0] \\
(0.5237)\end{array}$ & $\begin{array}{c}-2.0352515115[0] \\
(0.9721)\end{array}$ \\
\hline \multirow{2}{*}{ CrD } & $-1.823419191[0]$ & $-2.923419191[0]$ \\
& $(0.4236)$ & $(0.7821)$ \\
\hline \multirow{2}{*}{ Employee } & $-1.271691261[0]$ & $-2.782515111[0]$ \\
& $(0.2716)$ & $(0.7625)$ \\
\hline
\end{tabular}

AIC has been used to find the suitable length of lag. Thus, the unit root test was been done to the entire variable to determine the significant of this variable. The test has been run by using the EVIEW software and Augmented Dickey Fuller type of test are been used to test the unit root test. The variable test at level and first difference by using the constant and constantplus time trend test equation. It has been confirmed by the study that the variables involved in the study are integrated of first order. To check the long run relationship among the variables and its nature, the co-integration test has been performed. The variables in the null hypothesis were co-integrated against the alternative hypothesis. The results show the existence of co-integration. (Engle \& Granger, 1987) did the pioneering work on co-integration analysis and this was extended by Stock and Watson (1988), Johansen and Juselius (1990). The presence of co-integration association between $\ln$ GDP with $\ln 1$ tc, $\ln$ RGDP and $\ln$ inf, $\ln$ etc, $\ln \mathrm{cdr}$, has been tested in this study. And the last relationship is $\ln$ gdp with $\ln$ emp. The co-integration test based on Johensen's approach run by using EViews and the results are presented in table 2.

Table 2. Johensen's Test

\begin{tabular}{|c|c|c|c|c|}
\hline $\begin{array}{c}\text { Hypothesized } \\
\text { No. of CE }\end{array}$ & Eigenvalue & $\begin{array}{c}\text { Trace } \\
\text { Statistics }\end{array}$ & $\begin{array}{c}0.5 \text { Critical } \\
\text { Value }\end{array}$ & Prob*** \\
\hline None* & 0.2364 & 24.18721 & 21.79261 & 0.0000 \\
\hline At most $1 *$ & 0.3451 & 11.26121 & 08.78162 & 0.0000 \\
\hline At most $2 *$ & 0.4721 & 74.16309 & 68.78301 & 0.0000 \\
\hline At most 3* & 0.5237 & 42.12671 & 41.79999 & 0.0000 \\
\hline At most 4* & 0.4236 & 17.89012 & 12.52371 & 0.0000 \\
\hline At most 5* & 0.2364 & 04.28091 & 03.09872 & 0.0000 \\
\hline At most $6 *$ & 0.1982 & 06.01728 & 04.84146 & 0.0000 \\
\hline
\end{tabular}

Granger Causality test are used to test the causality relationship between the variables. The empirical result in the chapter is analyzed by using a multivariate Granger Causality test in order to examine the relation between the variables in this study. Following table will shows the result of the test (Table 3). 
Table 3. Granger causality test

\begin{tabular}{|c|c|c|}
\hline Excluded & Chi-sq & Prob. \\
\hline \multicolumn{3}{|c|}{ Model 12} \\
\hline RGDP & 34.651 & 0.000 \\
\hline L-RGDP & 20.219 & 0.000 \\
\hline Edu & 78.236 & 0.000 \\
\hline All & 133.106 & 0.000 \\
\hline \multicolumn{3}{|l|}{ Model 13} \\
\hline RGDP & 31.721 & 0.000 \\
\hline L-edu & 17.182 & 0.000 \\
\hline Edu & 53.236 & 0.000 \\
\hline All & 102.39 & 0.000 \\
\hline \multicolumn{3}{|c|}{ Model 14} \\
\hline RGDP & 14.613 & 0.000 \\
\hline Inf & 10.222 & 0.000 \\
\hline L-GDP & 21.236 & 0.000 \\
\hline All & 46.071 & 0.000 \\
\hline \multicolumn{3}{|c|}{ Model 15} \\
\hline RGDP & 32.231 & 0.000 \\
\hline Inf & 12.762 & 0.000 \\
\hline L-INF & 28.236 & 0.000 \\
\hline All & 73.229 & 0.000 \\
\hline \multicolumn{3}{|c|}{ Model 16} \\
\hline RGDP & 21.651 & 0.000 \\
\hline Expt & 17.219 & 0.000 \\
\hline L-RGDP & 21.236 & 0.000 \\
\hline All & 60.521 & 0.000 \\
\hline \multicolumn{3}{|c|}{ Model 17} \\
\hline RGDP & 21.023 & 0.000 \\
\hline Expt & 2.321 & 0.000 \\
\hline L-Expt & 8.091 & 0.000 \\
\hline All & 31.435 & 0.000 \\
\hline \multicolumn{3}{|c|}{ Model 18} \\
\hline RGDP & 34.231 & 0.000 \\
\hline Crd & 20.219 & 0.000 \\
\hline L-RGDP & 11.226 & 0.000 \\
\hline All & 65.676 & 0.000 \\
\hline \multicolumn{3}{|c|}{ Model 19} \\
\hline RGDP & 21.644 & 0.000 \\
\hline Crd & 19.233 & 0.000 \\
\hline L-Crd & 21.276 & 0.000 \\
\hline All & 62.153 & 0.000 \\
\hline \multicolumn{3}{|c|}{ Model 20} \\
\hline RGDP & 21.132 & 0.000 \\
\hline Employee & 20.765 & 0.000 \\
\hline L-RGDP & 8.321 & 0.000 \\
\hline All & 50.218 & 0.000 \\
\hline \multicolumn{3}{|c|}{ Model 21} \\
\hline RGDP & 34.261 & 0.000 \\
\hline Employee & 28.279 & 0.000 \\
\hline L-Employee & 11.260 & 0.000 \\
\hline All & 73.800 & 0.000 \\
\hline
\end{tabular}


This study formulated a simple growth model that used time series data technique to examine the relationship between education, health, employment and economy growth in Thai using Johensen Co Integrated test, Ordinary Least Square model, and the Granger Causality Test. This study attempted to investigate the statistical properties of the explanatory variables within a time series ADF test by using AIC statistic. It is clearly indicated by the AIC empirical results that all the variables of time series data are integrated of order 1 . This means that first difference has been taken to make the variables stationary. However, empirical support has been provided by Johensen Co-Integrated test that conintegration exists for the variables with GDP. The OLS results are shown in the table 4 below

Table 4. OLS results

\begin{tabular}{cc}
\hline $\begin{array}{c}\text { Dependent Variable: } \\
\boldsymbol{R} \boldsymbol{G} \boldsymbol{D P}\end{array}$ & Model 5 \\
\hline Edu & $0.213^{* * *}$ \\
Inf & $-0.239^{* *}$ \\
ExptR & $0.321^{*}$ \\
Crd & $0.244^{*}$ \\
Employee & $0.293^{*}$ \\
$\boldsymbol{R}^{\wedge} \mathbf{2}$ & $\mathbf{0 . 8 2 1}$ \\
\hline
\end{tabular}

Three important findings are extracted from the analysis in accordance to the objectives of this study. Firstly, does the education proxy variable literacy rate have relationship with the economy growth and determine the causality relationship either have direct relationship or not with the economy growth. Secondly, does health proxy variable (infant mortality rate, expectancy life rate and crude death rate) have relationship with the economy growth and also determine the causality relationship between this variable. Finally, the objective, does employment rate have relationship with the economy growth and determine the causality relationship between it.

\section{Conclusion}

Several important conclusions can be drawn from the study. Firstly, the general objective of this study is to examine the relationship between education, health, employment and economy growth in Thai during the period from 1982 - 2010. The finding of the unit root test on the variables in this study consistent with the result of a number of previous study such as DAI, Delpachitra, Cottrell (2017) and Bedir (2016). The OLS test was conducted to test the relationship and the results shows that the education variables have positive relationship with the economy growth, which means when the economy growth increase, the education or literacy rate in Thai also will increase. Next follow by the health variables, the positive relationship shown by the expectancy life rate with the economy growth. The expectancy rate shows a positive relationship with the GDP due to improvement in health sectors, environment and develop in nutrition due to economy growth extension. Other than that, infant mortality rate and crude death rate variables show a negative relationship with the economy growth. Whereby, when the economy growth keeps increasing, the infant mortality rate and crude death rate will decrease follow through the improvement in health sector and new technology in the medical line. The employment rates show a positive relationship with the economy growth. Positive relationship are shown because the economy growth will increased the government spending and increased the public sector project and training facilities which lead to employment rate increased (Haile \& Niño-Zarazúa, 2018). Secondly, this study provides the impact of education, health, employment towards economic growth in Thai. From the result of Johensen Co Integration test, there a strong evidence that all the time series data are in fact co integrated of order one. It means all the independent variable ltc, inf, etc, cdr, and emp and the dependent variables (gdp) are in fact integrated of order one. The result shows that there is long run co integration among this variable. In other words, there long run equilibrium exists among the variables. That means the education, health and employment has a positive impact to the economic growth in Thai. 
Thirdly, this study also provides the causality relationship between the variables and the economic growth. The results show that all the variables successful rejected the null hypothesis with economy growth and shows that the variable has direct relationship with the economy growth. In other hand, the results also show that the economy growth does not have direct relationship with the variables. It does can be happen because there is other major policy such as monetary and fiscal policy controlling the economy growth. Overall, the education, health, and employment have relationship with the Thai economy growth. Thus, these variables provide their contribution toward the economic and has impact in the long run. Therefore, the government has play it role in decrease or increase the impact of this variable or either to remain the relationship among the variables in long term, the question which was arise in section 1 and the objective is answered and achieve it.

\section{References}

Aghion, P., Comin, D., \& Tecu, I. (2016). When does domestic savings matter for economic growth? IMF Economic Review, 64(3), 381-407. https://doi.org/10.1057/imfer.2015.41

Bader, Y., \& Ganguli, S. (2019). Analysis of the association between economic growth, environmental quality and health standards in the Gulf Cooperation Council during 1980-2012. Management of Environmental Quality: An International Journal. http://dx.doi. org/10.1108/MEQ-03-2018-0061

Bedir, S. (2016). Healthcare expenditure and economic growth in developing countries. Advances in Economics and Business, 4(2), 76-86. http://dx.doi.org/10.13189/aeb.2016.040202

Bernardi, A. (2019). The capability approach and organizational climate as tools to study occupational health and safety, Insights into Regional Development 1(2): 155-169. https://doi.org/10.9770/ird.2019.1.2(6)

Beville, P. (2018). Foundations for Economic Development in Latin America: Naval Postgraduate School Monterey United States.

Bongaarts, J., Mensch, B. S., \& Blanc, A. K. (2017). Trends in the age at reproductive transitions in the developing world: the role of education. Population studies, 71(2), 139-154. https://doi.org/10.1080/00324728.2017.1291986

Chistobaev, A.I., Semenova, A.Z., Grudtsyn, N.A. (2018). Dynamics and strategic directions of public health preservation in Russian Federation, Entrepreneurship and Sustainability Issues, 6(3), 1180-1192. . http://doi.org/10.9770/jesi.2019.6.3(23)

DAI, P. V., Delpachitra, S., \& Cottrell, S. (2017). Real exchange rate and economic growth in East Asian countries: The role of financial integration. The Singapore Economic Review, 62(01), 163-177. https://doi.org/10.1142/S0217590816500168

Delgado, R., \& Stefancic, J. (2017). Critical race theory: An introduction (Vol. 20): NYU Press.

Ehrenberg, R. G., \& Smith, R. S. (2017). Modern labor economics: Theory and public policy: Routledge. https://doi. org/10.4324/9781315101798

Enders. (1995). Applied econometric time series, John Wiley\&Sons. Inc., New York. http://dx.doi.org/10.4236/am.2014.521315

Enders. (2004). Higher education, internationalisation, and the nation-state: Recent developments and challenges to governance theory. Higher education, 47(3), 361-382. http://dx.doi.org/10.1023/B:HIGH.0000016461.98676.30

Engle, R. F., \& Granger, C. W. (1987). Co-integration and error correction: representation, estimation, and testing. Econometrica: journal of the Econometric Society, http://dx.doi.org/10.2307/1913236

Farley, J., \& Voinov, A. (2016). Economics, socio-ecological resilience and ecosystem services. Journal of environmental management, 183, 389-398. https://doi.org/10.1016/j.jenvman.2016.07.065

Felipe, J., \& McCombie, J. (2019). The Illusions of Calculating Total Factor Productivity and Testing Growth Models: From CobbDouglas to Solow and to Romer. Available at SSRN 3377758. http://dx.doi.org/10.22617/WPS190486-2

Fleming, P. (2017). The human capital hoax: Work, debt and insecurity in the era of Uberization. Organization Studies, 38(5), 691-709. https://doi.org/10.1177\%2F0170840616686129

Gomes, C., F., De Mello Costa De Liberal, M., Dobbins Abi Rached, Ch. (2019). Cost management in a multi-Professional small-Scale clinic of popular health services. International Journal of Entrepreneurship, 23(2), 1-13.

Greiner, A., Semmler, W., \& Gong, G. (2016). The forces of economic growth: a time series perspective: Princeton University Press. https://doi.org/10.1515/9781400880157 
Gujarati, D. (2006). Econometría, México, MacGraw Hill, 4.

Haile, F., \& Niño-Zarazúa, M. (2018). Does Social Spending Improve Welfare in Low-income and Middle-income Countries? Journal of International Development, 30(3), 367-398. https://doi.org/10.1002/jid.3326

Harper, C., Harper, C. L., \& Snowden, M. (2017). Environment and society: Human perspectives on environmental issues: Routledge. https://doi.org/10.4324/9781315463254

Hossain, S. (2008). Econometrics modelling: Frequently asked questions. Cyberjava: Faculty of Managment, Multimedia University.

Hussain, H.I., Grabara, J., Razimi, M.S.A., \& Sharif, S.P. (2019) Sustainability of Leverage Levels in Response to Shocks in Equity Prices: Islamic Finance as a Socially Responsible Investment, Sustainability, 11 (12), 3260. https://doi.org/10.3390/su11123260

Ijaz, M. (2018). Does Poverty Reduction Cause Economic Development? Sukkur IBA Journal of Economics and Finance, 2(1), 36-54.

Jermsittiparsert, K. \& Sriyakul, T. (2014). The Development of Population Potential and National Power by Elevating the Professional Standard for Sport Coaches. Asian Social Science, 10(10), 188-198. http://dx.doi.org/10.5539/ass.v10n10p188

Jermsittiparsert, K, Sriyakul, T., \& Pamornmast, C. (2014). Minimum Wage and Country's Economic Competitiveness: An Empirical Discourse Analysis. The Social Sciences, 9(4), 244-250. http://dx.doi.org/10.3923/sscience.2014.244.250

Johansen, S., \& Juselius, K. (1990). Maximum likelihood estimation and inference on cointegration—with applications to the demand for money. Oxford Bulletin of Economics and statistics, 52(2), 169-210. https://doi.org/10.1111/j.1468-0084.1990.mp52002003.x

Kareem, R. (2015). Employment level and economic growth of Nigeria. Journal of Sustainable Development Studies, 8(1).

Khusaini, M. (2016). The role of public sector expenditure on local economic development. International Journal of Economic Policy in Emerging Economies, 9(2), 182-193. https://doi.org/10.1504/IJEPEE.2016.077279

Kvangraven, I. H. (2016). The changing character of financial flows to Sub-Saharan Africa Financial Deepening and Post-Crisis Development in Emerging Markets (pp. 223-245): Springer. http://dx.doi.org/10.1057/978-1-137-52246-7_11

MacKinnon, J. G. (1991). Critical values for cointegration tests. Paper presented at the Eds.), Long-Run Economic Relationship: Readings in Cointegration.

Munim, Z. H., \& Schramm, H.-J. (2018). The impacts of port infrastructure and logistics performance on economic growth: the mediating role of seaborne trade. Journal of Shipping and Trade, 3(1), 1. https://doi.org/10.1186/s41072-018-0027-0

Olusoji, M. O. (2016). A cross causal analysis of employment and economic growth in Nigeria. The Indian Journal of Labour Economics, 59(4), 553-562. https://doi.org/10.1007/s41027-017-0072-5

Organization, W. H. (2015). WHO global disability action plan 2014-2021: Better health for all people with disability: World Health Organization.

Ozturk, A. (2016). Examining the economic growth and the middle-income trap from the perspective of the middle class. International Business Review, 25(3), 726-738. https://doi.org/10.1016/j.ibusrev.2015.03.008

Padhan, P. C. (2008). The monetary policy transmission from official rate to unofficial rate under liquidity adjustment facility in India. Savings and Development, 191-207.

Panfiluk, E., Szymańska, E. (2017). The measurement of the innovativeness of health tourism services using an adequacy matrix title of the article. Entrepreneurship and Sustainability Issues 4(4): 400-420. http://doi.org/10.9770/jesi.2017.4.4(1)

Piore, M. (2017). Unemployment and inflation: institutionalist and structuralist views: Routledge. https://doi.org/10.4324/9781315084374

Pred, A. (2017). City-systems in advanced economies: past growth, present processes and future development options: Routledge. https://doi.org/10.4324/9781315103136

Rabushka, A., \& Kress, M. (2019). The New China: Comparative Economic Development in Mainland China, Taiwan, and Hong Kong: Routledge. https://doi.org/10.4324/9780429313066

Rafindadi, A. A. (2016). Does the need for economic growth influence energy consumption and CO2 emissions in Nigeria? Evidence from the innovation accounting test. Renewable and Sustainable Energy Reviews, 62, 1209-1225. https://doi.org/10.1016/j.rser.2016.05.028

Reinhold, K., Järvis, M., Prause, G. (2019). Occupational health and safety aspects of green shipping in the Baltic Sea. Entrepreneurship 
and Sustainability Issues, 7(1), 10-24. http://doi.org/10.9770/jesi.2019.7.1(1)

Rindermann, H., Kodila-Tedika, O., \& Christainsen, G. (2015). Cognitive capital, good governance, and the wealth of nations. Intelligence, 51, 98-108. https://doi.org/10.1016/j.intell.2015.06.002

Salter, A. W., \& Young, A. T. (2019). Polycentric sovereignty: The medieval constitution, governance quality, and the wealth of nations. Social Science Quarterly, 100(4), 1241-1253. https://doi.org/10.1111/ssqu.12619

Samargandi, N., Fidrmuc, J., \& Ghosh, S. (2015). Is the relationship between financial development and economic growth monotonic? Evidence from a sample of middle-income countries. World Development, 68, 66-81. https://doi.org/10.1016/j.worlddev.2014.11.010

Schwartz, H. M. (2019). States Versus Markets: Understanding the Global Economy: Macmillan International Higher Education.

Shuaibu, M. (2016). Determinants of human capital development in Africa: a panel data analysis. Oeconomia Copernicana, 7(4), 523549. http://dx.doi.org/10.12775/OeC.2016.030

Stock, J. H., \& Watson, M. W. (1988). Variable trends in economic time series. Journal of Economic Perspectives, 2(3), 147-174.

Wei, H., Ren, J., \& Zhou, J. (2013). Effect of exponential fertilization on growth and nutritional status in Buddhist pine (Podocarpus macrophyllus [Thunb.] D. Don) seedlings cultured in natural and prolonged photoperiods. Soil Science and Plant Nutrition, 59(6), 933-941. https://doi.org/10.1080/00380768.2013.864957

Werfalli, M. (2019). Informing the development of a self-management care programme for older people with type 2 diabetes attending community health centres in Cape Town, South Africa. Faculty of Health Sciences.

Wooldridge, J. M. (2009). Econometrics. Cengage Learning India Pvt. Ltd New Delhi.

Wooldridge, J. M. (2016). Introductory econometrics: A modern approach: Nelson Education.

Somdech RUNGSRISAWAT is an Associate Professor in Communication of Suan Sunandha Rajabhat University, Thailand, holding the Ph.D. in Communication from University of Westminster, U.K. He has been the Vice President for Academic Affairs and a senior researcher at SSRU since 2011. His areas of his expertise are Education, Communication, Business Administration, Marketing, IMC, Advertising, Public Relations, Image and Brand Building, and Interdisciplinary Research for Social Sciences. https://orcid.org/00000002-6985-6945

Chayongkan PAMORNMAST holds Ph.D. in Banking and Finance from University of New South Wales, Australia. He currently is a Head of Banking and Finance Department, Faculty of Business Administration, Mahanakorn University of Technology, Thailand.

This work is licensed under the Creative Commons Attribution International License (CC BY). http://creativecommons.org/licenses/by/4.0/ 